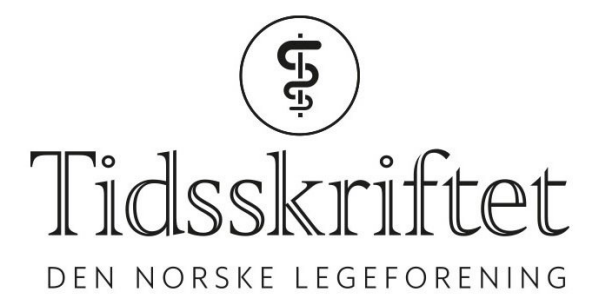

\title{
Pasienter med Lyme-borreliose går glipp av behandling
}

DEBATT

PER H. BJARK

E-post: per.bjark@gmail.com

Per H. Bjark er spesialist i infeksjonssykdommer og pensjonert sykehuslege.

Forfatter har fylt ut ICMJE-skjemaet og oppgir følgende interessekonflikter: Han har mottatt honorar for å være rettsoppnevnt sakkyndig i borreliosesaker.

Blir Lyme-borreliose riktig diagnostisert og behandlet?

Etter kontakt med en rekke pasienter kan jeg fastslå at pasienter med mistenkt Lymeborreliose uten patologiske funn i spinalvæske ikke sjelden får beskjed om at de ikke har nevroborreliose og heller ingen annen Lyme-borreliose som kan behandles med antibiotika. Det dreier seg vanligvis om sammensatte sykdomsbilder med muskel- og leddsmerter, fatigue og ikke sjelden hukommelses- og konsentrasjonsvansker. I Roaldsnes og medarbeideres artikkel i Tidsskriftet hadde 110 pasienter vurdert for mulig nevroborreliose «uspesifikke nevrologiske symptomer» som langvarig tretthet, konsentrasjonsproblemer og myalgier (1). Kun én pasient ble diagnostisert med mulig nevroborreliose. 27 \% hadde høye nivåer av borrelia-IgG-antistoffer i serum. Det sies ingenting om at det var aktuelt å vurdere for noen annen forløpsform av borreliose. Mange av pasientene hadde hatt symptomer i over et år. Det er vanskelig å lese artikkelen annerledes enn at om man har hatt slike symptomer så lenge, er borreliose en uaktuell diagnose. Samme budskap gjentas i en lederartikkel, der det konkluderes med at pasientene som ikke oppfyller diagnostiske krav til aktiv Lyme-nevroborreliose, uansett antistoffnivå eller sykehistorie, ikke skal ha «feilbehandling med antibiotika» (2).

Langvarig sykdomsbilde med fatigue, myalgier og høye borrelia-IgG-antistoffer i serum er ikke en ikke-sykdom. Enkelte nevrologer fornekter eksistensen av muskel-skjelettborreliose. Begrepet brukes likevel av Lyme-borreliosens "far», Allen Steere (3). Ubehandlet kan man ikke vite om dette er pasienter som profitterer på standard borreliarettet antibiotikabehandling. Jeg har sett mange av disse pasientene, og mener de skal behandles. Min erfaring er at de symptommessig ofte responderer langsomt, uten at det tilsier noen ekstra langvarig antibiotisk behandling. Bedringen er trolig knyttet til normalisering av cytokiner og eliminering av borreliaspesifikke immunkomplekser over tid. Vi har dessverre ingen tilgjengelige tester i dag som gjør det mulig å følge slike markører i rekonvalesensen. Populasjonsstudier på borrelia-seropositivitet bør ikke brukes for å innta et standpunkt mot behandling i klinisk suspekte tilfeller med positiv serologi (4). Vurdering av annen klinisk forløpsform enn nevroborreliose synes likevel å bli ekskludert (1). En artikkel fra Nederland blir dessverre også trukket inn som støtte for standpunktet $(2,5)$. Kritiske 
svakheter ved denne har jeg kommentert tidligere (6).

Det er alvorlig at vi gjennom manglende oppfølging her til lands stimulerer til behandlingsreiser til utenlandske sentre hvor oppleggene etter dagens kunnskap ikke kan forsvares infeksjonsmedisinsk eller ut fra et ønske om å redusere antbiotikabruken. Lymeborreliose arter seg klinisk meget varierende (3). Etter min lange erfaring med et stort antall tilfeller av Lyme-borreliose, mener jeg hver enkelt pasient må vurderes individuelt. Gjør vi ikke det, gjør vi mange pasienter urett.

\section{LITTERATUR:}

1. Roaldsnes E, Eikeland R, Berild D. Lyme-nevroborreliose ved uspesifikke nevrologiske symptomer. Tidsskr Nor Legeforen 2017; 137: 101-4. [PubMed][CrossRef]

2. Mygland Å. Kan det være Lyme-nevroborreliose? Tidsskr Nor Legeforen 2017; 137: 86. [PubMed][CrossRef]

3. Steere AC, Coburn J, Glickstein L. Lyme borreliosis. I: Goodman JL, Dennis DT, Sonenshine DE, red. Tick-borne diseases of humans. Washington, DC: ASM Press, 2005: 176-206.

4. Hjetland R, Reiso H, Ihlebæk C et al. Subjective health complaints are not associated with tick bites or antibodies to Borrelia burgdorferi sensu lato in blood donors in western Norway: a cross-sectional study. BMC Public Health 2015; 15: 657. [PubMed][CrossRef]

5. Berende A, ter Hofstede HJ, Vos FJ et al. Randomized trial of longer-term therapy for symptoms attributed to Lyme disease. N Engl J Med 2016;374:1209-20. [PubMed][CrossRef]

6. Bjark PH. Re: Ikke langvarig antibiotikabehandling ved sykdom tilskrevet borreliose. Tidsskr Nor Legeforen 2016; 136: 1702-3. [PubMed][CrossRef]

Publisert: 15. februar 2019. Tidsskr Nor Legeforen. DOI: 10.4045/tidsskr.18.0964

Mottatt 14.12.2018, første revisjon innsendt 9.1.2019, godkjent 14.1.2019.

(C) Tidsskrift for Den norske legeforening 2020. Lastet ned fra tidsskriftet.no 